\section{Response of Human Lymphocytes In Vitro to Two Dietary Furans, Furfuryl Alcohol and 2-Furyl Methyl Ketone}

\author{
Pillai Sasidharan Sujatha*,1 \\ Genetic Toxicology Laboratory, Department of Genetics, Os- \\ mania University, Hyderabad 500007, India
}

(Received April 24, 2007; Accepted October 20, 2007)

The genotoxicity of furfuryl alcohol and 2-furyl methyl ketone was assessed in human lymphocytes in vitro using standard chromosome aberration analysis and sister chromatid exchange (SCE) analysis. Three doses ranging from 240 to $960 \mathrm{ppm}$ which corresponded to in vivo doses were selected. Lymphocytes were cultured using TC-199 medium plus required supplements and initiated using blood drawn from healthy human donors who had not been exposed to any drugs or chemicals for a substantial period of time. After 24, 48, and $72 \mathrm{hr}$ of compound exposure, slides were prepared and analyzed for variations in the mitotic index (MI) and chromosome aberrations. For SCE analysis, $10 \mu \mathrm{g}$ of 5-bromodeoxy uridine was added $24 \mathrm{hr}$ after culture initiation and slides were prepared and stained using the standard technique. Two hundred metaphase spreads were scored per dose per period to analyze chromosome aberrations, and $\mathbf{5 0 0 0}$ cells were randomly scored to calculate the MI. Seventy-five metaphase spreads in second mitotic divisions were scored for each dose and period for SCE analysis. All data were subjected to stastical analysis. There was an insignificant induction of chromosome aberrations and mitodepression (MD), while SCEs showed an increased incidence with both compounds which was dose and period dependent.

Key words — furfuryl alcohol, 2-furyl methyl ketone, 5-bromodeoxy uridine, sister chromatid exchange analysis, mitotic index, mitodepresssion

\footnotetext{
${ }^{1}$ Present address: Department of Zoology, Faculty of Science, The Maharaja Sayaji Rao University of Baroda, Vadodara, Gujarat-390002, India. Tel.: +91-95-0265-2371408. Fax: +9195-0265-2787356; E-mail: pillaisujatha@yahoo.co.in *To whom correspondence should be addressed: Genetic Toxicology Laboratory, Department of Genetics, Osmania University, Hyderabad 500007, India.
}

\section{INTRODUCTION}

The environment contains several potential inducers of cancer and hence carries mutagenic risks. They include natural or synthetic agents such as radiation, numerous chemicals, food additives, drugs, dietary compounds, and pesticides. ${ }^{1)}$ Many of them are genotoxic and carcinogenic in animal models. Some mutagenic compounds are naturally reactive to DNA, while others undergo enzymatic reactions to become electrophilic species ${ }^{2-4)}$ to bind with DNA, RNA, and proteins.

Epidemiologic data show that diet is a crucial factor in the etiology of human cancer. ${ }^{5)}$ The dietary furans, furfuryl alcohol and 2-furyl methyl ketone, occur in a variety of vegetarian and non vegetarian foods ${ }^{6)}$ and have wide industrial applications. ${ }^{7)}$ Furans and related compounds are toxic to animals and humans after bioactivation. ${ }^{8,9)}$ They are reported to induce hepatic, pulmonary, and renal toxicity. ${ }^{10)}$ Earlier investigations in our laboratory revealed their clastogenicity, mitodepression, cytotoxicity, and induction of sister chromatid exchanges (SCEs) in an in vivo experimental mouse system. ${ }^{11-14)}$ The information available on their activity in an in vitro system is highly fragmentary. Stitch et al. ${ }^{15)}$ reported the clastogenic activity of some furans in Chinese Hamster Ovary (CHO) cells in the presence of S-9 mix. It was shown in vitro that the reactive intermediates covalently bind to tissue macromolecules in hepatic and pulmonary microsomal systems. ${ }^{10)}$ Gomez-Arroyo and Souza ${ }^{16)}$ reported the induction of SCEs in human lymphocytes in vitro with furfural but their absence in occupationally exposed persons.

Although furfuryl alcohol and 2-furyl methyl ketone were shown to induce clastogenicity, cytotoxicity, and SCEs in animal models in our previous studies, it is necessary to determine the activity of these two furans in an in vitro system without any metabolic activation and confirm whether the compounds themselves are genotoxic or their metabolic conversion in the body is necessary to make them genotoxic. Many mutagenic compounds undergo chemical or enzymatic conversions in cells to become electrophilic species and cause mutations. We therefore used in vitro human lymphocyte cultures to assess the activity of furfuryl alcohol and 2-furyl methyl ketone without any metabolic activation.

SCEs result from DNA interchanges between replication products at homologous regions following breakage and reunion of DNA. They serve as 
elegant cellular dosimeters to evaluate mutagenic events occurring at the molecular level. As these two furans were shown to induce SCEs significantly in an in vivo mouse test system, ${ }^{17)}$ we attempted to evaluate them in vitro using this endpoint and compare the in vivo data with the in vitro results.

\section{MATERIALS AND METHODS}

Dose Selection — Three doses of the two compounds ranging from $240-960 \mathrm{ppm}$ were computed on a blood volume basis to correspond to in vivo doses. ${ }^{14)}$ Fifty microliters of the desired concentrations of compounds (furfuryl alcohol, 240, 480 and 960 ppm, 99\% pure, Oxoid, Basingstock, Hampshire, U.K.; and 2-furyl methyl ketone, 240, 480 and $720 \mathrm{ppm}$, 99\% pure, Fluke, AG, Switzerland, Germany) were added 0,24 , and $48 \mathrm{hr}$ after initiation of culture to correspond to 72-, 48-, and 24-hr exposure to the test compounds at the time of termination. The highest dose selected for 2-furyl methyl ketone was $720 \mathrm{ppm}$ since the dose corresponding to $960 \mathrm{ppm}$ in an in vivo system was found to be lethal. ${ }^{13)}$

Selection of Donors — The mitotic rate and cell cycle are specific to each individual and vary from person to person. Their response to different drugs also varies. ${ }^{17,18)}$ Hence control and treated cultures were prepared from the same donors in the agegroup of 20-25 years and of the same sex. Precautions were taken so that they were not exposed to any drug, chemical, or other agent.

In vitroculture — In vitro cultures were prepared according to the standard microculture method ${ }^{19)}$ using TC-199 medium (Schwartz Bioresearch, Schwartz Bioresearch, Orange burg, New York, U.S.A.) supplemented with human $\mathrm{AB}^{+}$serum (20\%), phytohaemagglutinin (PHA, Difco Laboratories, Difco Lab. Michigan, U.S.A.) and antibiotics (dicrysticine-S-Fortis, Sarabhai Chemicals, Vadodara, India). Seven cultures per day (1 control and 6 treated) were allowed to grow for 24,48 , and $72 \mathrm{hr}$, respectively. Blood $(3.5 \mathrm{ml})$ was collected in heparinized syringes by venipuncture and added to each culture vial in $0.5-\mathrm{ml}$ volumes. After mixing thoroughly, the samples were incubated at $37^{\circ} \mathrm{C}$ for $72 \mathrm{hr}$.

To assess the effect of the furans on cultures, the test concentrations of compounds in a volume of $50 \mu \mathrm{l}$ were added 0,24 , and $48 \mathrm{hr}$ after initiation of culture to correspond to 72-, 48-, and 24-hr ex- posure, respectively to the test substance at culture termination. Most cells undergo the first division in culture after $40-54 \mathrm{hr}$ while some of them are in their second division at $72 \mathrm{hr}^{20}$ )

Two hours prior to harvesting, three drops of colchicine $(7.14 \mu \mathrm{g} / \mathrm{ml})$ were added to each culture vial and mixed well. After $72 \mathrm{hr}$, slides were prepared according to the standard air-drying method.

Chromosome Aberration Analysis — Two hundred well spread metaphases were scored for each dose and period to analyze various chromosome aberrations. To assess the action of these furans on cell proliferation, 5000 cells were randomly scored for each dose and period and analyzed for variations in mitotic indices using the following formulae:

$$
\begin{aligned}
& \text { Mitotic index }(\mathrm{MI}) \\
& \quad=\frac{\text { No. of cells in division } \times 100}{\text { Total no. of cells scored }} \\
& \text { Mitodepression }(\mathrm{MD}) \\
& \quad=\frac{\text { MI }(\text { control })-\text { MI (treated }) \times 100}{\text { MI (control) }}
\end{aligned}
$$

SCE Analysis — Cultures were prepared in the same same manner as for chromosome aberration analysis described above. After $24 \mathrm{hr}$ of culture, $10 \mu \mathrm{g}$ of 5-bromodeoxy uridine (5-Brdu, Sigma Chemical, St. Louis, MO, U.S.A.) was added to each culture and covered with black paper to avoid photolysis. ${ }^{21)}$ Slides were prepared using standard air-drying method, stored in the dark for 2-3 days, and processed for differential staining using the method of Perry and Wolff. ${ }^{22)}$ Seventy five well differentiated second metaphases were scored for each dose and period.

All experiments were repeated three times and results are expressed as mean \pm S.E.

Stastical Analysis — Statistical analysis was carried out using Woolf's modified chi-square test ${ }^{23}$ ) for chromosome aberration analysis, $2 \times 2$ contingency test ${ }^{24)}$ for variations in mitotic index, and Student's $t$-test for SCE analysis. A $t$-value of less than 0.05 was considered to represent a statistically significant difference.

\section{RESULTS AND DISCUSSION}

Human lymphocytes in vitro undergo mitosis after blast transformation when cultured with PHA. The majority of cells are in the first metaphase after $48 \mathrm{hr}$ and reach the second metaphase after $72 \mathrm{hr}^{20}{ }^{20}$ Hence exposure of the cells to test compounds for 
Table 1. Chromosomal Aberrations and Mitodepression Induced by Furfuryl Alcohol In Vitro

\begin{tabular}{|c|c|c|c|c|c|c|c|}
\hline \multirow{2}{*}{$\begin{array}{c}\text { Period } \\
(\mathrm{hr})\end{array}$} & \multirow{2}{*}{$\begin{array}{l}\text { Dose } \\
(\mathrm{ppm})\end{array}$} & \multirow[t]{2}{*}{ Mitotic index } & \multirow[t]{2}{*}{ Mitodepression } & \multicolumn{2}{|c|}{ Structural aberrations } & \multirow{2}{*}{$\begin{array}{l}\text { Numerical } \\
\text { aberrations }\end{array}$} & \multirow{2}{*}{$\begin{array}{c}\text { Other } \\
\text { aberrations }\end{array}$} \\
\hline & & & & With gaps & Without gaps & & \\
\hline \multirow[t]{4}{*}{24} & Control & 3.40 & - & 1 & - & - & 1 \\
\hline & 240 & 3.32 & 2.35 & - & - & - & 6 \\
\hline & 480 & 3.24 & 4.71 & 2 & 2 & - & 3 \\
\hline & 960 & 3.16 & 7.06 & 4 & 2 & - & 5 \\
\hline \multirow[t]{4}{*}{48} & Control & 3.64 & - & 1 & 1 & - & 1 \\
\hline & 240 & 3.44 & 5.49 & 4 & 2 & - & - \\
\hline & 480 & 3.40 & 6.59 & 5 & 2 & 1 & - \\
\hline & 960 & 3.30 & 9.34 & 5 & 3 & - & 1 \\
\hline \multirow[t]{4}{*}{72} & Control & 3.50 & - & 1 & - & - & 1 \\
\hline & 240 & 3.36 & 4.00 & - & - & 1 & - \\
\hline & 480 & 3.22 & 8.00 & - & - & - & 2 \\
\hline & 960 & 3.10 & 11.43 & 5 & 2 & - & 2 \\
\hline
\end{tabular}

Structural aberrations include gaps, breaks, dicentrics, and fragments. Numerical aberrations include polyploidy and endoreduplication. Other aberrations include satellite associations and centromeric associations.

Table 2. Chromosomal Aberrations and Mitodepression Induced by 2-Furyl Methyl Ketone In Vitro

\begin{tabular}{|c|c|c|c|c|c|c|c|}
\hline \multirow{2}{*}{$\begin{array}{c}\text { Period } \\
(\mathrm{hr})\end{array}$} & \multirow{2}{*}{$\begin{array}{c}\text { Dose } \\
(\mathrm{ppm})\end{array}$} & \multirow[t]{2}{*}{ Mitotic index } & \multirow[t]{2}{*}{ Mitodepression } & \multicolumn{2}{|c|}{ Structural aberrations } & \multirow{2}{*}{$\begin{array}{l}\text { Numerical } \\
\text { aberrations }\end{array}$} & \multirow{2}{*}{$\begin{array}{l}\text { Other } \\
\text { rrations }\end{array}$} \\
\hline & & & & With gaps & Without gaps & & \\
\hline \multirow[t]{4}{*}{24} & Control & 3.40 & - & 1 & - & 1 & 1 \\
\hline & 240 & 3.36 & 1.18 & 一 & - & 一 & - \\
\hline & 480 & 3.20 & 5.88 & - & 一 & 一 & 1 \\
\hline & 720 & 3.10 & 8.82 & 2 & 2 & 1 & 1 \\
\hline \multirow[t]{4}{*}{48} & Control & 3.64 & - & - & 1 & - & 1 \\
\hline & 240 & 3.52 & 3.29 & 5 & & 1 & 2 \\
\hline & 480 & 3.40 & 6.59 & 1 & 一 & - & 1 \\
\hline & 720 & 3.24 & 10.98 & 5 & 3 & - & 5 \\
\hline \multirow[t]{4}{*}{72} & Control & 3.50 & - & 1 & 一 & 一 & 一 \\
\hline & 240 & 3.40 & 2.86 & 一 & - & 1 & 3 \\
\hline & 480 & 3.36 & 4.00 & 5 & 3 & 2 & 5 \\
\hline & 720 & 3.20 & 8.57 & 6 & 3 & - & 5 \\
\hline
\end{tabular}

Structural aberrations include gaps, breaks, dicentrics, and fragments. Numerical aberrations include polyploidy and endoreduplication. Other aberrations include satellite associations and centromeric associations.

different periods gives a good indication of activity at various stages of the cell cycle.

Tables 1 and 2 show the activity of furfuryl alcohol and 2-furyl methyl ketone on human lymphocytes in vitro. There was a decrease in the rate of cell proliferation as the MI declined after culture with both compounds. However, the induction of MD was not statistically significant compared with control cultures. The sporadic incidence of chromosomal aberrations observed included gaps, breaks, fragments, centromeric associations and others. Although there was a slight increase in their incidence in test cultures, it was not statistically significant (Tables 1 and 2).
In our earlier studies, furfuryl alcohol and 2furyl methyl ketone were found to be mitodepressive and mildly clastogenic in the mouse bone marrow system. ${ }^{13)}$ Furans are reported to produce reactive electrophilic intermediates after metabolic activation which react with nucleic acids, proteins, or other macromolecules. ${ }^{7)}$ The absence of mutagenicity in the present study suggests that metabolic activation is necessary for clastogenicity, as reported for other furans like furfural and 5-methyl furfural. ${ }^{15)}$

SCE analysis is an elegant dosimeter for detecting mutagenicity at the cellular level. ${ }^{21)}$ SCEs are consequences of DNA interchanges between replication products at homologous regions following 
Table 3. Sister Chromatid Exchanges Induced by Furfuryl alcohol and 2-Furyl Methyl Ketone In Vitro

\begin{tabular}{|c|c|c|c|c|c|c|c|}
\hline \multirow{2}{*}{$\begin{array}{l}\text { Period } \\
\text { (hr) }\end{array}$} & \multirow{2}{*}{$\begin{array}{l}\text { Dose } \\
(\mathrm{ppm})\end{array}$} & \multicolumn{3}{|c|}{ Furfuryl alcohol } & \multicolumn{3}{|c|}{ 2-Furyl methyl ketone } \\
\hline & & $\begin{array}{l}\text { SCEs } \\
\text { scored }\end{array}$ & $\begin{array}{c}\text { SCEs } \backslash \text { Cell } \\
(\text { mean } \pm \text { S.E. })\end{array}$ & $t$-values & $\begin{array}{l}\text { SCEs } \\
\text { scored }\end{array}$ & $\begin{array}{c}\text { SCEs } \backslash \text { Cell } \\
\text { (mean } \pm \text { S.E.) }\end{array}$ & $t$-value \\
\hline \multirow[t]{5}{*}{24} & Control & 235 & $3.13 \pm 0.66$ & - & 235 & $3.14 \pm 0.66$ & - \\
\hline & 240 & 311 & $4.15 \pm 0.54$ & 2.09 & 240 & $3.20 \pm 0.84$ & 0.11 \\
\hline & 480 & 345 & $4.60 \pm 0.28$ & $2.88^{*}$ & 365 & $4.86 \pm 0.40$ & $3.93^{*}$ \\
\hline & 720 & - & - & - & 375 & $5.00 \pm 0.62$ & $6.93^{* *}$ \\
\hline & 960 & 338 & $4.50 \pm 0.50$ & 2.85 & - & - & - \\
\hline \multirow[t]{5}{*}{48} & Control & 249 & $3.32 \pm 0.33$ & - & 249 & $3.32 \pm 0.33$ & - \\
\hline & 240 & 380 & $5.07 \pm 0.70$ & $3.98^{*}$ & 283 & $3.77 \pm 0.40$ & 1.50 \\
\hline & 480 & 403 & $5.37 \pm 0.51$ & $5.85^{* *}$ & 428 & $4.37 \pm 0.45$ & $3.28^{*}$ \\
\hline & 720 & - & - & - & 426 & $5.68 \pm 0.35$ & $6.56^{* *}$ \\
\hline & 960 & 465 & $6.20 \pm 0.72$ & $6.40^{* *}$ & - & - & - \\
\hline \multirow[t]{5}{*}{72} & Control & 217 & $2.90 \pm 0.36$ & - & 217 & $2.90 \pm 0.36$ & - \\
\hline & 240 & 210 & $2.80 \pm 0.66$ & 0.23 & 310 & $4.13 \pm 0.35$ & $4.24^{*}$ \\
\hline & 480 & 272 & $3.63 \pm 0.35$ & 2.52 & 330 & $4.40 \pm 0.75$ & $3.13^{*}$ \\
\hline & 720 & - & - & - & 405 & $5.50 \pm 1.44$ & $2.94^{*}$ \\
\hline & 960 & 325 & $4.33 \pm 1.14$ & 2.07 & - & - & - \\
\hline
\end{tabular}

${ }^{*}$ Significant at $5 \%$ level (expected value is 2.78$) .{ }^{* *}$ Significant at $1 \%$ level (expected value is 4.60$)$.

the breakage and reunion of DNA. Although furfuryl alcohol and 2-furyl methyl ketone were found to be nonclastogenic in in vitro systems, SCE analysis was carried out to determine whether they were able to produce SCEs under culture conditions because many clastogens are reported to be noninducers of SCEs while many nonclastogens are SCE inducers. ${ }^{25)}$ Table 3 shows the induction of SCEs after furfuryl alcohol and 2-furyl methyl ketone exposure. A significant induction of SCEs was found after $24 \mathrm{hr}$ with the two higher doses of furfuryl alcohol and with all doses after $48 \mathrm{hr}$ treatment. The frequency declined after $72 \mathrm{hr}$ and was not significant. Culture with 2-furyl methyl ketone resulted in significant SCE induction at the two higher doses after 24 and $48 \mathrm{hr}$ and with all doses after $72 \mathrm{hr}$ (Table 3). The incidence of SCEs was higher in lymphocytes cultured with 2-furyl methyl ketone. With both compounds there was an increase in SCEs from lower to higher doses with an increase from 24 to $48 \mathrm{hr}$ and a decline there after. The decrease in the later period may be due to the repair of lesions, death of lesion-bearing cells or lack of persistence of chemical activity at the target site. ${ }^{14,26)}$

It has been established that the mechanism involved in the induction of SCEs and chromosomal aberrations are different. ${ }^{27,28)}$ Hence the absence of induction of chromosomal aberrations by furfuryl alcohol and 2-furyl methyl ketone in vitro and occurrence of SCEs following exposure even at low concentrations is not surprising since there are reports that low concentrations of a mutagen can produce significant SCEs, ${ }^{21,29)}$ while some known clastogens like bleomycin and ionizing radiation are poor SCE inducers. ${ }^{30,31)}$ In our earlier studies with in vivo mouse system, analysis of chromosome aberrations from bone marrow showed an increased incidence of structural aberrations only at the highest concentrations ${ }^{1-13)}$ whereas SCE analysis was positive for all concentrations. ${ }^{14)}$ While these results indicate the chromosomal mutation activity of the two furans in vivo, SCE data from the present study provide further evidence to support their activity at the DNA level although they failed to show clastogenicity in vitro. These results are in conformity with those of Gomez-Arroyo and Souza ${ }^{16)}$ who showed that furfural, a furan derivative induced SCEs in human lymphocytes in vitro. They also showed the absence of induction of SCEs after 72$\mathrm{hr}$ exposure to furfuryl alcohol in vitro. However, the results from the present study compared different durations of exposure and found evidence for the induction of SCEs in earlier periods. Other dietary furans like 2-methyl furan and 2,5-dimethyl furan also induced SCEs in human lymphocytes in vitro. ${ }^{26)}$

There are no reports on the long-term exposure of humans to any furan derivative. Animal models have demonstrated cytotoxicity or carcinogenicity to the liver, nasal tract, central nervous sys- 
tem and kidney after long-term exposure to many furans. ${ }^{32,33)}$ In our studies, furfuryl alcohol and 2furyl methyl ketone induced cytotoxicity and stress proteins at up to 90 days of exposure in mouse models. ${ }^{34)}$ Hence the present study is significant as humans are constantly exposed to furans either through diet or the environment.

Acknowledgements Dr. P. S. Sujatha is grateful to the University Grants Commission for a Senior Research Fellowship. She is highly indebted to late Prof. S. Subramanyam for his invaluable guidance.

\section{REFERENCES}

1) Ames, B. N. and Gold, L. D. (1990) Too many rodent carcinogens: Mitogenesis increases mutagenesis. Science, 249, 970-971.

2) Ashby, J. (1982) Screening of chemicals for mutagenecity-Practise and pitfalls. In Mutagenecity-New Horizon in Genetic Toxicology (Heddle, J. A., Ed.), Academic Press, New York, pp. 1-33.

3) Cleaver, J. E. (1984) Methods for studying excision repair of eukaryotic DNA damaged by physical and chemical mutagens. In Handbook of Mutagenicity Test Procedures (Kilby, B. J., Legator, M., Nichols, W. and Ramel, C., Eds.), Elsevier Science Publishers, Amsterdam, pp. 34-69.

4) Rudiger, H. W. (1990) Endogenous carcinogens. Implications of an emerging concept. Mutat. Res., 238, 173-174.

5) Doll, R. and Peto, R. (1981) The causes of cancer: Quantitative estimates of avoidable risk of the cancer in the United States today. J. Natl. Cancer Inst., 66, 1192-1305.

6) Maga, J. A. (1979) Furans in foods. CRC Crit. Rev. Food Sci. Nutr., 11, 355.

7) Burka, L. T., Washburn, K. D. and Irwin, R. D. (1991) Disposition of ${ }^{14} \mathrm{C}$ furan in the male F344 rat. J. Toxicol. Environ. Health, 34, 245-257.

8) Burka, L. T. and Boyd, M. R. (1985) Furans. In Bioactivation of Foreign Compounds (Anders, M.W., Ed.), Academic Press, New York, pp. 243257.

9) Ravindranath, V., McMenamin M. G., Dees, J. H. and Boyd, M. R. (1986) 2-methyl furan toxicity in rats-Role of metabolic activation in vivo. Toxicol. Appl. Pharmacol., 85, 78-91.

10) Ravindranath, V., Burka, L. T. and Boyd, M. R. (1984) Reactive metabolites from the bioactivation of toxic methyl furans. Science, 224, 884-886.
11) Sujatha, P. S. and Subramanyam, S. (1993) Genotoxic evaluation of furfuryl alcohol in mouse meiocyte test system. J. Cytol. Genet, 28, 13-17.

12) Sujatha, P. S., Jayanyhi, A. and Subramanyam, S. (1993) Evaluation of clastogenic potential of 2-furyl methyl ketone in in vivo mouse system. Med. Sci. Res., 21, 675-678.

13) Sujatha, P. S. and Subramanyam, S. (1994) Clastogenicity of furfuryl alcohol in mouse bone marrow system. Med. Sci. Res., 22, 281-284.

14) Sujatha, P. S. (2007) Genotoxic evaluation of furfuryl alcohol and 2-furyl methyl ketone by sister chromatid exchange (SCE) analysis. J. Health Sci., 53, 124-127.

15) Stich, H. F., Rosin, M. P., Wu, C. H. and Powerie, W. D. (1981) Clastogenecity of furans found in food. Cancer Lett., 13, 89-95.

16) Gomez-Arroyo, S. and Souza, V. S. (1985) In vitro and occupational induction of SCEs in human lymphocytes with furfuryl alcohol and furfural. Mutat. Res., 156, 233-238.

17) Heddle, J. A., Evans, H. J. and Scott, D. (1967) Sampling time and the complexity of the human leucocyte culture system. In Human Radiation Cytogenetics (Evans, H. J., Courtbrown, R. M. and Melan, A. S. Eds.), North Holland Publishing, Amsterdam.

18) Schoeller, L. and Wolff, V. (1970) Possibilities and limitations of chromosomes treated in vitro for the problem of chemical mutagenesis. In Chemical Mutagenesis in Mammals and Man (Vogel, F. and Rohrborn, G. Eds.), Springer, Berlin, Heidelberg, New York, pp. 232-250.

19) Arakaki, D. T. and Sparks, R. S. (1963) Microtechnique for culturing leucocytes from whole blood. Cytogenetics, 2, 57-60.

20) Buckton, K. E. and Evans, H. J. (1973) Methods for the analysis of human chromosome aberrations, WHO Publication, Geneva, pp. 1-66.

21) Latt, S. A., Allen, J. W., Rogers, W. E. and Juergens, L. A. (1997) In vitro and in vivo analysis of sister chromatid exchange formation. In Handbook of Mutagenicity Test Procedures (Kilby, B. J., Legator, M., Nichols, W. and Ramel, C., Eds.), Elsevier, Amsterdam, pp. 275-291.

22) Perry, P. and Wolff, S. (1974) New Giemsa method for the differential staining of sister chromatids. $\mathrm{Na}$ ture, 251, 156-158.

23) Pillai, S. K. and Sinha, H. C. (1968) Statistical Methods for Biological Workers, Ram Prasad and Sons, Agra, India, pp. 85-87.

24) Li, C. C. (1961) Human Genetics: Principles and Methods, McGraw Hill, London, Toronto, New York, pp. 92-95. 
25) Perry, P. E. (1978) Chemical mutations and sister chromatid exchanges. In Chemical Mutagenesis, Principles and Methods for Their Detection (Seres, F. J. D. and Hollander, A., Eds.), Plenum Press, New York, U.S.A., pp. 1-39.

26) Ratnaprabha, D. (1991) Evaluation of genotoxic potentials of two methyl furans by cytogenetic parameters. Ph.D Thesis, Osmania University, Hyderabad, India.

27) Kato, H. (1997) Mechanism for sister chromatid exchanges and their relation to the production of chromosomal aberrations. Chromosoma, 59, 179-191.

28) Galloway, S. M. and Wolff, S. (1979) The relation between chemically induced SCEs and chromatid breakage. Mutat. Res., 61, 297-307.

29) Bradley, M. V., Hsu, I. C. and Harris, C. C. (1979) Relationship between sister chromatid exchanges, mutagenicity, toxicity and DNA damage. Nature, 282, 318-320.

30) Perry, P. E. and Evans, H. J. (1975) Cytological de- tection of mutagen carcinogen exposure by sister chromatid exchanges. Nature, 258, 121-125.

31) Gebhart, E. (1978) Chromosome aberrations induced in persons exposed to chemical mutagens. Proceedings of the International Symposium on Environmental Agents and Their Biological Effects. Indian Journal of Heredity, 11, 12-20.

32) Health and Safety Executive (2005) Health and Safety Executive Publications-Chemical Hazard Alert Notice, 33. Furfuryl alcohol, http://www. hse.Govtuk/pubns/chan.33

33) National Toxicology Programme (1999) Toxicology and carcinogenesis studies of furfuryl alcohol (CASNo.98-UD-0) in F344/N rats and B6C3F1 mice (inhalation studies). NTP Technical Report Series, 482, NH publication. No. 99, 3972. Research Triangle Park, North Carolina, U.S.A.

34) Sujatha, P. S. (2007) Monitoring cytotoxicity of furfuryl alcohol and 2-furyl methyl ketone in mice. Food and Chemical Toxicology, 46, 286-292. 